\title{
Dowex-50W-Promoted Synthesis of Oxazoline, Imidazoline and Thiazoline Derivatives
}

\author{
Ayoob Bazgir ${ }^{*}$, Mostafa M. Amini* and Yousef Fazaeli \\ Department of Chemistry, Shahid Beheshti University, Tehran 198396311, General Campus, Iran
}

\begin{abstract}
Dowex-50W-hyodrgen ion exchange resin was used as a reusable catalyst for the synthesis of oxazoline, imidazoline and thiazoline derivatives through condensation reaction between arylnitriles and 2-aminoalcohol, ethylenediamine or 2-aminoethanthiol. This process provides several advantages such as excellent yields of the products, simple operation, convenient separation and inexpensive and recyclable catalyst.
\end{abstract}

Keywords: Dowex-50W, oxazoline, imidazoline, thiazoline, recyclable catalyst.

\section{INTRODUCTION}

One of the main themes of contemporary synthetic organic chemistry is the development of atom-economic and environmentally benign catalytic systems [1]. In this context, the development of heterogeneous catalysis is of prime importance not only from the economic point of view, but also due to the easy work-up procedures involved in the separation of the catalyst products from reactions mixture. Accordingly, various solid acids such as zeolites, clays, alumina, heteropolyacids, and acidic resins have been tested in heterogeneous system [2-5]. Each catalyst has its own advantages and disadvantages. It is always interesting to develop a new environmental benign catalyst for organic transformations.

On the other hand, heterocyclic compounds occur very widely in nature and are essential to life. Nitrogencontaining heterocyclic molecules constitute the largest portion of chemical entities, which are part of many natural products, fine chemicals, and biologically active pharmaceuticals vital for enhancing the quality of life [6]. Among a large variety of nitrogen-containing heterocyclic compounds, heterocycles containing an oxazoline, imidazoline and thiazoline moiety are of interest because they constitute an important class of natural and synthetic products, many of which exhibit useful biological activities and clinical applications [7-11]. Furthermore, these compounds, have recently received great attention because of their wide range of therapeutic and biological properties, such as antihypertensive [12], antidiabetic [13], anticancer $[14,15]$ and antialzheimer [16] activities. They are also known as important intermediates in organic transformations [17].

Various procedures have been disclosed in order to synthesize oxazoline, imidazoline and thiazoline derivatives by employing precursors such as aldehydes [18], amides [19], esters [20], aziridines [21], and nitriles [22-26]. In spite

*Address correspondence to these authors at the Department of Chemistry, Shahid Beheshti University, Tehran 198396311, General Campus, Iran; Tel: 98-21-29903109; Fax; 98-21-22431663;

E-mails: a_bazgir@sbu.ac.ir, m-pouramini@cc.sbu.ac.ir of potential utility of aforementioned routes for the synthesis of oxazoline, imidazoline and thiazoline derivatives, many of these methods involve expensive reagents, strong acidic conditions, long reaction times, low yields and use of toxic organic solvents. Therefore, to avoid these limitations, the discovery of a new and efficient catalyst with high catalytic activity, short reaction time, recyclability and simple workup for the preparation of these compounds under neutral, mild and practical conditions is of prime interest. The aim of this study is to utilize the Dowex-50W ion exchange resin as catalyst for the synthesis of oxazoline, imidazoline and thiazoline derivatives.

\section{EXPERIMENTAL}

Melting points were measured on an Electrothermal 9200 apparatus and are uncorrected. IR spectra were recorded on FT-IR 102MB BOMEM apparatus. ${ }^{1} \mathrm{H}$ NMR and ${ }^{13} \mathrm{C}$ NMR spectra were determined on a BRUKER DRX-300 AVANCE spectrometer at 300.13 and $75.47 \mathrm{MHz}$, respectively. MS spectra were recorded on a Shimadzu QP $1100 \mathrm{EX}$ mass spectrometer operating at an ionization potential of $70 \mathrm{eV}$. Dowex-50W-hydrogen ion exchange resin was purchased from Aldrich and used as received.

2.1. General Procedure for the Preparation of Oxazolines, Thiazolinse and Imidazolines (3)

A mixture of nitrile (1 mmol), 2-aminoalcohol, ethylenediamine or 2-aminoethanthiol $(2 \mathrm{mmol})$ and resin $(0.2 \mathrm{~g})$ was heated at $80{ }^{\circ} \mathrm{C}$ for an appropriate time. The reaction monitored TLC. After cooling to r.t., reaction mixture was washed with $\mathrm{EtOH}(10 \mathrm{~mL})$ and catalyst was filtered off. The solvent was evaporated and the crude product was purified by recrystalization in $n$-hexane or by column chromatography.

All the products are known compounds and were characterized by IR and NMR spectroscopic data and their melting points are compared with the reported values [22-26].

2-phenyl-4,5-dihydro-1H-imidazole (7a): $\mathrm{mp} 99-101{ }^{\circ} \mathrm{C}$; $\operatorname{IR}(\mathrm{KBr})\left(v_{\max }, \mathrm{cm}^{-1}\right): 3210,1603 ;{ }^{1} \mathrm{H}$ NMR $\left(\mathrm{CDCl}_{3}\right): \delta_{\mathrm{H}} 3.74$ $\left(4 \mathrm{H}, \mathrm{s}, 2 \mathrm{CH}_{2}\right), 4.95(1 \mathrm{H}, \mathrm{s}, \mathrm{NH}), 7.32-7.71(5 \mathrm{H}, \mathrm{m}, \mathrm{H}-$ Arom.); ${ }^{13} \mathrm{C}$ NMR $\left(\mathrm{CDCl}_{3}\right): \delta_{\mathrm{C}} 50.5,115.2,128.5,133.3$, 135.2, 165.7. MS (m/z, \%): $146\left(\mathrm{M}^{+}, 15\right), 144$ (35), 77 (100). 
2-(pyridin-4-yl)-4,5-dihydrothiazole (5d): m.p. $75-77^{\circ} \mathrm{C}$; IR (KBr) $\left(v_{\max }, \mathrm{cm}^{-1}\right): 3007,1598 \mathrm{~cm}^{-1}$; ${ }^{1} \mathrm{H}$ NMR $\left(\mathrm{CDCl}_{3}\right)$ : $\delta_{\mathrm{H}} 3.46\left(2 \mathrm{H}, \mathrm{t}, J=8.8 \mathrm{~Hz}, \mathrm{CH}_{2} \mathrm{~S}\right), 4.49(2 \mathrm{H}, \mathrm{t}, J=8.7 \mathrm{~Hz}$, $\left.\mathrm{CH}_{2} \mathrm{~N}\right)$, 7.70-8.67 (4H, m, H-Arom.); ${ }^{13} \mathrm{C}$ NMR $\left(\mathrm{CDCl}_{3}\right): \delta_{\mathrm{c}}$ 33.4, 51.6, 124.1, 142.6, 149.0, 159.9; MS (m/z, \%): 165 $\left(\mathrm{M}^{+}+1,20\right), 136$ (45), 78 (100).

\section{RESULTS AND DISCUSSION}

Considering the above reports and in continuation of our previous works on the application of heterogeneous catalysts for development of useful synthetic methodology [27-30], we wish to report a simple, efficient and practical approach for the synthesis of oxazoline, imidazoline and thiazoline derivatives using Dowex-50W ion exchange resin as ecofriendly catalysts with high catalytic activity under solventfree conditions.

The reaction conditions were optimized by examining the amount of catalyst for the reaction involving 4-chlorobenzonitrile (1b) (1 mmol) and 2-aminoalcohol (2a) (2 $\mathrm{mmol})$ to afforded the product (3b) under solvent-free conditions at $80{ }^{\circ} \mathrm{C}$ (Scheme 1). The best results was obtained with a $0.2 \mathrm{~g}$ catalyst under solvent-free conditions and gave 2-(4-chlorophenyl)-4,5-dihydrooxazole (3b) in high yield.

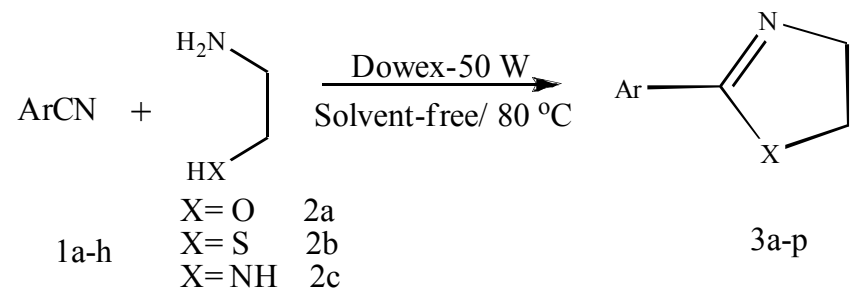

Scheme 1. Preparation of oxazolines, imidazolines and thiazolines catalyzed by Dowex- 50 .

Dowex-50W ion exchange resin catalyzed the condensation of 2-aminoalcohol (2a) or 2-aminoethanthiol (2b) or ethylenediamine (2c) and a wide range of aromatic nitriles (1) under solvent-free conditions at $80{ }^{\circ} \mathrm{C}$. As indicated in Table 1, in all cases the reaction gives the products in good yields and prevents problems which many associate with solvent use such as cost, handling, safety and pollution. In these experiments, the isolation of the catalyst from reaction mixture could be easily performed by its suspension in EtOH. The used catalyst was dried at $50{ }^{\circ} \mathrm{C}$ for $1 \mathrm{~h}$ and then reloaded with fresh reagents for further runs. Apparently, recycling of catalyst is possible for four successive times without significant loss of activity (Table $\mathbf{1}$, entries $\mathbf{2 b}, \mathbf{2 g}$ and $\mathbf{2 m}$ ). Finally, it should be mentioned when reactions were carried out in the absence of catalyst for long period of time $\left(12 \mathrm{~h}\right.$.) and in solvent-free conditions at $80{ }^{\circ} \mathrm{C}$ the yields of products were low $(<40 \%)$.

Under the same conditions, this reaction almost could not be observed when the alkylnitrile was used as a starting material. Therefore, the chemoselectivity of this method was demonstrated using equimolar mixture of arylnitrile and alkylnitrile. Smooth conversion of the arylnitrile to the corresponding oxazoline was observed while the alkylnitrile remained unaffected (Scheme 2).
Table 1. Preparation of Product 3 Using Dowex-50W Ion Exchange Resin

\begin{tabular}{|c|c|c|c|c|}
\hline Product 3 & Ar & $\mathbf{X}$ & Time (h) & Yield $(\%)^{\mathrm{a}}$ \\
\hline $\mathbf{a}$ & $\mathrm{C}_{6} \mathrm{H}_{5}$ & $\mathrm{O}$ & 3.5 & 85 \\
\hline b & 4-Cl- $\mathrm{C}_{6} \mathrm{H}_{4}$ & $\mathrm{O}$ & 3.2 & $87(86,87,85)^{b}$ \\
\hline c & 3-Cl- $\mathrm{C}_{6} \mathrm{H}_{4}$ & $\mathrm{O}$ & 3.5 & 85 \\
\hline d & 4-Me- $\mathrm{C}_{6} \mathrm{H}_{4}$ & $\mathrm{O}$ & 4 & 81 \\
\hline e & $4-\mathrm{CN}-\mathrm{C}_{6} \mathrm{H}_{4}$ & $\mathrm{O}$ & 3 & 86 \\
\hline f & $\mathrm{C}_{6} \mathrm{H}_{5}$ & $\mathrm{~S}$ & 0.3 & 91 \\
\hline g & 4-Cl- $\mathrm{C}_{6} \mathrm{H}_{4}$ & $\mathrm{~S}$ & 0.3 & $93(93,91,92)^{\mathrm{c}}$ \\
\hline h & 4-Me- $\mathrm{C}_{6} \mathrm{H}_{4}$ & S & 0.3 & 90 \\
\hline $\mathbf{i}$ & 4-CN-C ${ }_{6} \mathrm{H}_{4}$ & S & 0.3 & 91 \\
\hline $\mathbf{j}$ & 4-MeO- $\mathrm{C}_{6} \mathrm{H}_{4}$ & $\mathrm{~S}$ & 0.5 & 88 \\
\hline $\mathbf{k}$ & $4-\mathrm{NO}_{2}-\mathrm{C}_{6} \mathrm{H}_{4}$ & $\mathrm{~S}$ & 0.3 & 91 \\
\hline 1 & $\mathrm{C}_{6} \mathrm{H}_{5}$ & $\mathrm{NH}$ & 3 & 74 \\
\hline $\mathbf{m}$ & 4-Cl- $\mathrm{C}_{6} \mathrm{H}_{4}$ & $\mathrm{NH}$ & 3.5 & $90(89,90,88)^{\mathrm{c}}$ \\
\hline $\mathbf{n}$ & 4-Me- $\mathrm{C}_{6} \mathrm{H}_{4}$ & $\mathrm{NH}$ & 5 & 75 \\
\hline $\mathbf{o}$ & $4-\mathrm{CN}-\mathrm{C}_{6} \mathrm{H}_{4}$ & $\mathrm{NH}$ & 3.3 & 86 \\
\hline $\mathbf{p}$ & 4-MeO- $\mathrm{C}_{6} \mathrm{H}_{4}$ & $\mathrm{NH}$ & 6 & 74 \\
\hline
\end{tabular}

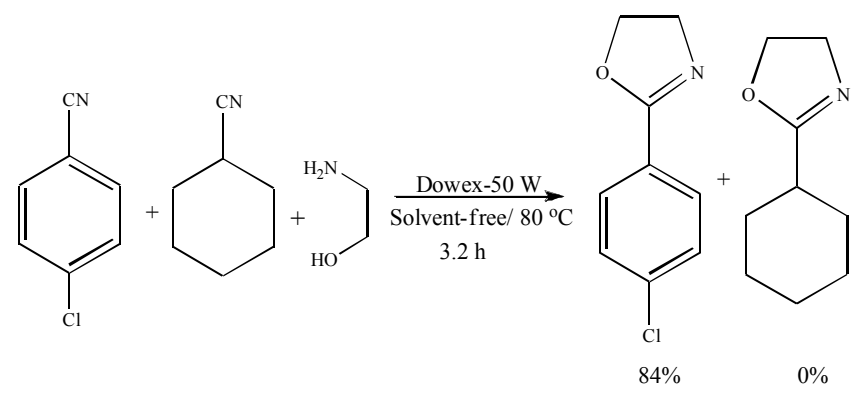

Scheme 2. Chemoselective synthesis of aryl oxazolines vs alkyl oxazolines.

\section{CONCLUSION}

In conclusion, we have developed a simple, efficient and green protocol for the synthesis of oxazoline, imidazoline and thiazoline derivatives using Dowex-50W under solventfree conditions. The simple work-up, a good yield, mild reaction conditions and recyclability of catalyst are features of this new procedure.

\section{ACKNOWLEDGMENTS}

We gratefully acknowledge the financial support from the Research Council of Shahid Beheshti University and CCE (Catalyst Center of Excellence).

\section{REFERENCES}

[1] Anastas, P.T.; Williamson, T.C. Eds.; Green Chemistry: Designing Chemistry for the Environment; ACS Symp. Ser.: Washington, DC, 1996.

[2] Olah, G. A. In: Fraissard J.; Petrakis L., Eds.; Acidity and Basicity of Solids, Kluwer, Dortrecht: Netherlands, 1994. 
[3] Izumi, Y.; Urabe, K.; Onaka, M. Zeolite, Clay, and Heteropoly Acids in organic reactions; VCH: New York, 1992.

[4] Singh, K.; Arora, D.; Singh, S. Dowex-promoted general synthesis of N,N'-disubstituted-4-aryl-3,4-dihydropyrimidinones using a solvent-free Biginelli condensation protocol. Tetrahedron Lett., 2006, 47, 4205 .

[5] Kidwai, M.; Mohan, R.; Rastogi, S. Alumina catalyzed synthesis of fused thioxopyrimidine derivatives under microwaves. Synth. Commun., 2003, 33, 3747.

[6] Garuti, L.; Roberts, M.; Pizzirani, D. Nitrogen-containing heterocyclic quinones: a class of potential selective antitumor agents. Mini-Rev. Med. Chem., 2007, 7, 481.

[7] Gant, T. G.; Meyers, A. I. The chemistry of 2-oxazolines (1985present). Tetrahedron, 1994, 50, 2297.

[8] Frump, J. A. Oxazolines. Their preparation, reactions, and applications Oxazolines. Their preparation, reactions, and applications. Chem. Rev., 1971, 71, 483.

[9] Grimmett, M. R. In: Comprehensive Heterocyclicl Chemistry, Vol. 3, Pergamon; Oxford, 1996.

[10] Gilman, A. G.; Goodman, L.S. The Pharmacological Basis of Therapeutics, $10^{\text {th }}$ ed.; McGraw-Hill: New York, 2001.

[11] Greenhill, J. V.; Lue, L. In: Ellis G.P.; Luscombe, D.K., Eds.; Progress in Medicinal Chemistry, Elsevier: New York, 1993, Vol. 3.

[12] Bousquet, P.; Feldman, J. Drugs acting on imidazoline receptors: A review of their pharmacology, their use in blood pressure control and their potential interest in cardioprotection. Drugs, 1999, 58, 799.

[13] Rondu, F.; Lr Bihan, G.; Wang, X.; Lamouri, A.; Touboul, E.; Dive, G.; Bellahsene, T.; Pfeiffer, B.; Renard, P.; GuardiolaLemaitre, B.; Manéchez, D.; Pénicaud, L.; Ktorza, A.; Godfroid, J. J. Design and synthesis of imidazoline derivatives active on glucose homeostasis in a rat model of type II diabetes. 1. Synthesis and biological activities of $N$-benzyl- $N^{\star}$-(arylalkyl)-2-(4',5'dihydro-1'H-imidazol-2'-yl)piperazines. J. Med. Chem., 1997, 40, 3793.

[14] Wipf, P.; Frith, P. C. Synthesis of peptide thiazolines from $\beta$ hydroxythioamides. An investigation of racemization in cyclodehydration protocols. Tetrahedron Lett., 1994, 35, 5397.

[15] Wipf, P.; Venkatraman, S. From aziridines to oxazolines and thiazolines: The heterocyclic route to thiangazole. Synlett, 1997, 1.

[16] Tomizawa, M.; Cowan, A.; Casida, J. E. Analgesic and toxic effects of neonicotinoid insecticides in mice. Toxicol. Appl. Pharmacol., 2001, 177, 77.

[17] Puntener, K.; Hellman, M. D.; Kuester, E.; Hegedus, L. S. Synthesis and complexation properties of poly(ethylene glycol)linked mono- and bis-dioxocyclams. J. Org. Chem., 2000, 65, 8301 .
[18] Fujioka, H.; Murai, K.; Kubo, O.; Ohba, Y.; Kita, Y. One-pot synthesis of imidazolines from aldehydes: detailed study about solvents and substrates. Tetrahedron, 2007, 63, 638.

[19] Brain, C. T.; Hallett, A.; Ko, S. Y. N-Thioacylation of $\beta$-amino alcohols by $\mathrm{N}$-(thioacyl)phthalimides: A facile synthesis of $\alpha$ amino acid thiazolines. Tetrahedron Lett., 1998, 39, 127.

[20] Zhou, P.; Blubaum, J. E.; Burns, C. T.; Natale, N. R. The direct synthesis of 2-Oxazolines from carboxylic esters using lanthanide chloride as catalyst. Tetrahedron Lett., 1997, 38, 7019.

[21] Ghorai, M. K.; Ghosh, K.; Das, K. Copper(II) triflate promoted cycloaddition of $\alpha$-alkyl or aryl substituted $N$-tosylaziridines with nitriles: a highly efficient synthesis of substituted imidazolines. Tetrahedron Lett., 2006, 47, 5399.

[22] Mohammadpoor-Baltork, I.; Khosropour, A. R.; Hojati, S. F. A novel and chemoselective synthesis of 2-aryloxazolines and bisoxazolines catalyzed by Bi(III) Salts. Synlett, 2005, 2747.

[23] Mohammadpoor-Baltork, I.; Khosropour, A. R.; Hojati, S. F. $\mathrm{ZrOCl}_{2} \cdot 8 \mathrm{H}_{2} \mathrm{O}$ as an environmentally friendly and recyclable catalyst for the chemoselective synthesis of 2-aryloxazolines and bis-oxazolines under thermal conditions and microwave irradiation Catal. Commun., 2007, 8, 200.

[24] Mirkhani, V.; Moghadam, M.; Tangestaninejad, S.; Kargar, H. Rapid and efficient synthesis of 2-imidazolines and bisimidazolines under ultrasonic irradiation. Tetrahedron Lett., 2006, 47, 2129.

[25] Mirkhani,V.; Mohammadpoor-Baltork, I.; Moghadam, M.; Tangestaninejad, S.; Abdoullahi -Alibeik, M.; Kargar, $\mathrm{H}$. $\mathrm{ZrOCl}_{2} \cdot 8 \mathrm{H}_{2} \mathrm{O}$ : An efficient and reusable catalyst for the synthesis of imidazolines and bis-imidazolines under various reaction conditions. Appl. Catal. A: Gen., 2007, 325, 99.

[26] Mohammadpoor-Baltork, I.; Mirkhani, V.; Moghadam, M.; Tangestaninejad, S.; Zolfigol, M.A.; Abdoullahi-Alibeik, M.; Khosropour, A. R.; Kargar, H.; Hojati, S. F. Catal. Commun., 2008, 9, 894.

[27] Amini, M. M.; Shaabani, A.; Bazgir, A. Tangstophosphoric acid $\left(\mathrm{H}_{3} \mathrm{PW}_{12} \mathrm{O}_{40}\right)$ : An efficient and eco-friendly catalyst for the one-pot synthesis of dihydropyrimidin-2(1H)-ones. Catal. Commun., 2006, 7,843 .

[28] Seyyedhamzeh, M.; Mirzaei, P.; Bazgir, A. Solvent-free synthesis of aryl-14H-dibenzo[a,j]xanthenes and 1,8-dioxo-octahydroxanthenes using silica sulfuric acid as catalyst. Dyes Pigm., 2008, 76,836 .

[29] Imani Shakibaei, G.; Mirzaei, P.; Bazgir, A. Dowex-50W promoted synthesis of 14-aryl-14H-dibenzo[a,j]xanthene and 1,8-dioxooctahydroxanthene derivatives under solvent-free conditions. Appl. Catal. A Gen., 2007, 325, 188.

[30] Amini, M. M.; Seyyedhamzeh, M.; Bazgir, A. Heteropolyacid: An efficient and eco-friendly catalyst for the synthesis of 14-aryl-14Hdibenzo[a,j]xanthene. Appl. Catal. A Gen., 2007, 323, 242. 